\title{
PENGARUH KOMPETENSI GURU TERHADAP HASIL BELAJAR EKONOMI DI SMA NEGERI RAMBIPUJI TAHUN AJARAN 2017/2018
}

\author{
Umu Syaidah $^{1}$, Bambang Suyadi ${ }^{1}$, Hety Mustika Ani ${ }^{1}$ \\ ${ }^{1}$ Program Studi Pendidikan Ekonomi, Fakultas Keguruan dan Ilmu Pendidikan, Universitas Jember \\ e-mail: 140210301056@students.unej.ac.id
}

\begin{abstract}
Abstrak
Tujuan penelitian ini untuk mengetahui pengaruh yang signifikan kompetensi guru terhadap hasil belajar ekonomi di SMA Negeri Rambipuji Tahun Ajaran 2017/2018. Kompetensi guru dalam penelitian ini menggunakan dua indikator, yaitu kompetensi pegadogik dan kompetensi profesional. Adapun penentuan sampel dalam penelitian ini menggunakan purposive area yakni siswa kelas XI IPS SMA Negeri Rambipuji Tahun Ajaran 207/2018 dengan jumlah responden 50 orang. Metode yang digunakan adalah analisis inferensial menggunakan regresi linier sederhana, analisis varian garis regresi, efektivitas garis regresi, uji $\mathrm{F}$ dan standart error of estimate. Uji instrumen yang digunakan adalah uji validitas dan uji reliabilitas. Hasil penelitian menunjukkan bahwa kompetensi guru memiliki pengaruh yang signifikan terhadap hasil belajar siswa di SMA Negeri Rambipuji. Hasil Uji $F$ menunjukkan $F_{\text {hitung }}=194,392>F_{\text {tabel }}=4,043$ dengan tingkat signifikansi $0,000<a=0,05$ dengan persamaan regresi sederhana $\hat{Y}=28,333+0,674 \mathrm{X}$. Hasil perhitungan koefisien determinasi $\left(\mathrm{R}^{2}\right)$ sebesar 0,802 , hal ini menunjukkan bahwa besarnya persentase pengaruh kompetensi guru terhadap hasil belajar ekonomi di SMA Negeri Rambipuji sebesar 80,2\%, sedangkan sisanya yakni $19,8 \%$ dipengaruhi oleh variabel bebas lain yang tidak diteliti dalam penelitian ini.
\end{abstract}

Kata Kunci: Kompetensi, Hasil Belajar, Kompetensi guru.

\section{PENDAHULUAN}

Tujuan pendidikan nasional adalah mencerdaskan kehidupan bangsa dan mengembangkan manusia Indonesia seutuhnya, yaitu manusia yang beriman dan bertaqwa terhadap Tuhan YME serta berbudi pekerti luhur, memiliki pengetahuan dan keterampilan, kesehatan jasmani dan rohani, kepribadian yang mantap dan mandiri serta rasa tanggung jawab kemasyarakatan dan kebangsaan. Dalam rangka mencapai tujuan pendidikan nasional dibutuhkan pendidik yang profesional. Sesuai dengan undang-undang Republik Indonesia No. 20 tahun 2003 tentang sistem pendidikan nasional, jabatan guru sebagai pendidik merupakan jabatan profesional. Oleh karena itu guru dituntut agar terus berkembang sesuai dengan zaman, ilmu pengetahuan dan teknologi serta kebutuhan masyarakat akan sumber daya manusia yang berkualitas dan memiliki daya saing yang dapat dihandalkan.

Seorang guru disebut sebagai guru profesional apabila memiliki kemampuan dalam mewujudkan kinerja profesi guru dengan sebaik-baiknya dalam mencapai tugas keprofesionalannya seperti yang tercantum di dalam UU No. 14 tahun 2005, Bab IV Pasal 20 (a) tentang Guru dan Dosen dalam melaksanakan tugas keprofesionalannya guru berkewajiban merencanakan, melaksanakan proses pembelajaran, serta menilai dan mengevaluasi hasil pembelajaran. Keoptimalan kerja guru juga harus selaras dengan tujuan pendidikan dan diintegrasikan dengan komponen sekolah, baik itu kepala sekolah, guru, karyawan maupun peserta didik.

SMA Negeri Rambipuji merupakan salah satu sekolah menengah atas di Kabupaten Jember, yang beralamat di Jl. Durian No. 30 Pecoro, Rambipuji, Jember. Berdasarkan hasil observasi awal dan wawancara dengan Waka kurikulum menunjukkan bahwa guru SMA Negeri Rambipuji sudah memenuhi standar kompetensi, hal ini didukung dengan persentase kualifikasi guru di SMA Negeri Rambipuji Tahun Ajaran 2017/2018 sudah 100\%. Artinya semua guru yang mengajar di SMA Negeri Rambipuji sudah memenuhi standar kualifikasi guru.

Kualifikasi guru merupakan keahlian yang diperlukan untuk melakukan pekerjaan guru dengan melalui pendidikan khusus keahlian. Guru pada tiap satuan pendidikan harus memenuhi kualifikasi akademik dengan bidang keilmuan yang relevan dengan bidang studi atau mata pelajaran yang mereka ajarkan di sekolahnya sehingga mereka disebut kompeten untuk bidang pekerjaannya. Guru yang kompeten akan lebih mampu menciptakan lingkungan belajar yang efektif, menyenangkan dan lebih mampu mengelola kelasnya sehingga hasil belajar siswa juga baik. 
Faktor ekstern yang penting dalam pendidikan formal salah satunya adalah guru, karena guru terlibat langsung dalam kegiatan pembelajaran, pembentukan dan pengembangan intelektual serta kepribadian siswa. Guru sering dijadikan tokoh teladan bahkan dijadikan tokoh identitas diri, dengan demikian guru harus memiliki perilaku, keterampilan, dan kemampuan yang memadai untuk melaksanakan tugasnya dengan baik. Baik tidaknya kualitas pendidikan akan terlihat dari kinerja dan kompetensi guru sebagai pendidik yang melaksanakan proses pembelajaran.

Guru dalam menjalankan tugasnya sebagai pendidik harus memiliki standar kompetensi yang mencakup: kompetensi pedagogik, kepribadian, sosial, dan profesional. Kompetensi guru adalah kemampuan seorang guru dalam penguasaan pengetahuan, keterampilan, nilai dan sikap dalam menjalankan tugas dan tanggungjawabnya. Seorang guru akan mampu menjalankan tugasnya dengan baik apabila memiliki kemampuan yang sesuai dengan bidang keahliannya. Guru dalam mengajar harus memiliki kompetensi mengajar agar mampu menciptakan lingkungan belajar yang efektif dan menyenangkan. Kompetensi guru yang profesional akan menjadikan mutu pendidikan di Indonesia lebih baik lagi.

Berdasarkan hasil observasi awal kompetensi guru di SMA Negeri Rambipuji sudah memenuhi keempat kompetensi tersebut. Kompetensi pedagogik dapat dilihat melalui kegiatan pembelajaran dan kemampuan mengembangkan proses pembelajaran serta dapat memahami cara berfikir siswa. Dalam menjalankan tugasnya guru juga memiliki kompetensi kepribadian, kompetensi ini merupakan kemampuan yang menjadikan guru sebagai pembimbing, panutan dan contoh serta teladan bagi siswa.

Guru juga memiliki kompetensi profesional, kompetensi ini tercermin dalam kemampuan guru menguasai materi pembelajaran dan mengembangkan materi sesuai dengan perkembangan teknologi terbaru. Terakhir adalah kompetensi sosial, kompetensi ini berkaitan dengan kemampuan guru dalam membina hubungan yang baik dengan peserta didik, sesama guru maupun dengan orang tua wali, hal ini dapat dilihat melalui cara guru berkomunikasi guru di sekolah dan di masyarakat.

Kualitas pendidikan pada suatu sekolah juga dapat dilihat dari hasil belajar para siswanya, jika hasil belajar siswa baik maka kualitas pendidikan sekolah tersebut baik, begitu pula sebaliknya. Belajar memegang peranan penting di dalam perkembangan, kebiasaan, sikap, keyakinan, tujuan, kepribadian dan bahkan persepsi manusia. Belajar adalah kegiatan yang berproses dan merupakan unsur yang sangat fundamental dalam penyelenggaraan setiap jenis dari jenjang pendidikan. Hal ini berarti berhasil atau tidak pembelajaran tergantung pada proses belajarnya, dimana proses belajar menentukan hasil belajar siswa.

Hasil belajar merupakan tolok ukur yang telah dicapai siswa setelah melakukan kegiatan pembelajaran selama waktu yang telah ditentukan. Selain itu hasil belajar juga digunakan untuk mengetahui kemampuan dan kualitas siswa setelah melakukan proses pembelajaran. Keberhasilan seorang siswa dalam belajar dapat dilihat dari hasil belajar siswa yang bersangkutan. Guru perlu mengadakan evaluasi hasil belajar, melalui evaluasi hasil belajar tersebut dapat dilihat hasil belajar siswa yang dicapai selama mengikuti proses belajar mengajar.

Salah satu faktor yang mempengaruhi hasil belajar siswa adalah kemampuan guru dalam melaksanakan kegiatan pembelajaran. Kegiatan pembelajaran yang optimal dan hasil belajar siswa yang baik merupakan harapan semua pihak namun kenyataan di lapangan masih menunjukkan kegiatan guru yang bekerja kurang optimal dan masih dijumpai hasil belajar siswa yang di bawah KKM cukup banyak. Masih ada beberapa guru yang kurang mengembangkan Rencana Pelaksanaan Pembelajaran (RPP) secara maksimal. Hal ini terlihat dari sederhananya RPP yang dibuat dan tidak disertai dengan media pembelajaran sebagai penunjangnya seperti peta konsep, power point, serta alat peraga yang mendukung kegiatan pembelajaran lainnya.

Masih ada guru yang datang terlambat ke sekolah, hal tersebut menyebabkan kegiatan pembelajaran menjadi sedikit terganggu. Selanjutnya adalah keterbatasan media pembelajaran dan penggunaan metode ceramah yang dominan membuat proses pembelajaran menjadi kurang variatif. Meskipun siswa dalam kegiatan pembelajaran tetap dapat mengikuti pembelajaran dengan kondusif dirasa hal ini perlu ditingkatkan dalam penggunaan media dan metode yang lebih bervariasi.

SMA Negeri Rambipuji sudah menyediakan berbagai fasilitas untuk kegiatan belajar mengajar seperti perpustakaan, laboratorium dan LCD proyektor, meskipun jumlahnya masih terbatas hal tersebut tetap dapat dimanfaatkan oleh guru sebagai sarana penunjang kegiatan pembelajaran secara bergantian. Berdasarkan uraian di atas dan pentingnya kompetensi guru serta hasil belajar siswa mendorong peneliti untuk melakukan penelitian 
yang bertujuan untuk mengetahui pengaruh yang signifikan Kompetensi guru tehadap hasil belajar ekonomi di SMA Negeri Rambipuji Tahun Ajaran 2017/2018.

\section{METODE}

Penelitian ini dilakukan dengan metode kuantitatif menggunakan analisis regresi linier sederhana. Adapun metode penentuan lokasi penelitian menggunakan purposive area dan penentuan sampel menggunakan purposive sampling, yakni siswa kelas XI IPS SMA Negeri Rambipuji dengan jumlah responden 50 orang. Metode pengumpulan data menggunakan kuesioner, wawancara dan dokumen. Analisis data yang digunakan adalah varian garis regresi, Uji F, dan koefisien determinasi, untuk memudahkan perhitungan analisis data maka peneliti menggunakan bantuan program SPSS 22.0 for windows.

\section{HASIL DAN PEMBAHASAN}

\section{Hasil Penelitian}

Hasil perhitungan analisis regresi linier sederhana dengan menggunakan program SPSS 22.0 for windows adalah sebagai berikut:

Tabel 1. Hasil analisis regresi linier sederhana

Coefficients $^{\mathrm{a}}$

\begin{tabular}{|c|c|c|c|c|c|c|}
\hline \multirow{2}{*}{\multicolumn{2}{|c|}{ Model }} & \multicolumn{2}{|c|}{$\begin{array}{c}\text { Unstandardized } \\
\text { Coefficients }\end{array}$} & \multirow{2}{*}{$\begin{array}{c}\begin{array}{c}\text { Standardized } \\
\text { Coefficients }\end{array} \\
\text { Beta }\end{array}$} & \multirow[b]{2}{*}{$\mathbf{t}$} & \multirow[b]{2}{*}{ Sig. } \\
\hline & & $\mathrm{B}$ & Std. Error & & & \\
\hline \multirow[t]{2}{*}{1} & (Constant) & 28,333 & 3,887 & & 7,290 & ,000 \\
\hline & Kompetensi guru & 674 &, 048 & ,896 & 13,942 & ,000 \\
\hline
\end{tabular}

a. Dependent Variable: Hasil Belajar Ekonomi

Berdasarkan data di atas, maka persamaan regresi sederhana yang diperoleh dalam penelitian ini adalah sebagai berikut:

$$
\hat{\mathbf{Y}}=28,333+0,674 X
$$

Adapun hasil perhitungan untuk analisis varian garis regresi adalah sebagai berikut:

Tabel 2. Hasil interpretasi model summary

Model Summary ${ }^{b}$

\begin{tabular}{|l|r|r|r|r|}
\hline Model & R & \multicolumn{1}{|c|}{ R Square } & $\begin{array}{c}\text { Adjusted R } \\
\text { Square }\end{array}$ & $\begin{array}{c}\text { Std. Error of } \\
\text { the Estimate }\end{array}$ \\
\hline 1 &, $896^{\mathrm{a}}$ &, 802 &, 798 & 2,371 \\
\hline
\end{tabular}

a. Predictors: (Constant), Kompetensi Guru

b. Dependent Variable: Hasil Belajar Ekonomi

Berdasarkan hasil data yang didapatkan seperti yang terlihat pada tabel di atas, maka diketahui besarnya nilai koefisien korelasi adalah 0,896. Koefisien korelasi sebesar 0,897 tersebut menunjukkan bahwa hubungan antara variabel (X) kompetensi guru terhadap variabel (Y) hasil belajar ekonomi di SMA Negeri Rambipuji Tahun Ajaran 2017/2018 dikategorikan mempunyai hubungan yang sangat kuat.

Hasil $R$ Square seperti yang terlihat pada tabel 2 sebesar 0,802 sehingga hasil akhir setelah dimasukkan ke dalam rumus koefisien determinasi $\left(\mathrm{R}^{2}\right)$ adalah sebagai berikut:

$$
R \text { Square } x 100 \%=0,802 \times 100 \%=\mathbf{8 0 , 2} \%
$$


Hal ini menunjukkan bahwa besarnya persentase pengaruh kompetensi guru terhadap hasil belajar ekonomi di SMA Negeri Rambipuji Tahun Ajaran 2017/2018 sebesar 80,2\%. Adapun perhitungan dari Uji F, diketahui nilai $\mathrm{F}_{\text {hitung }}$ sebagai berikut:

Tabel 3. Hasil uji F

ANOVA $^{\mathrm{a}}$

\begin{tabular}{|ll|r|r|r|r|r|}
\hline Model & & Sum of Squares & df & Mean Square & F & Sig. \\
\hline 1 & Regression & 1092,994 & 1 & 1092,994 & 194,392 &, $000^{\mathrm{b}}$ \\
& Residual & 269,886 & 48 & 5,623 & & \\
& Total & 1362,880 & 49 & & & \\
\hline
\end{tabular}

a. Dependent Variable: Hasil Belajar Ekonomi

b. Predictors: (Constant), Kompetensi Guru

Berdasarkan data di atas, diketahui bahwa nilai $\mathrm{F}_{\text {hitung }}=194,392$ lebih besar dari $\mathrm{F}_{\text {tabel }}=4,043$ dengan tingkat signifikansi 0,000 lebih kecil dari $a=0,05$. Hal ini menunjukkan bahwa variabel kompetensi guru memiliki pengaruh yang signifikan terhadap hasil belajar ekonomi di SMA Negeri Rambipuji Tahun Ajaran $2017 / 2018$.

\section{Pembahasan}

Hasil analisis inferensial yang telah dijabarkan di atas diketahui bahwa kompetensi guru memiliki pengaruh yang signifikan terhadap hasil belajar ekonomi di SMA Negeri Rambipuji Tahun Ajaran 2017/2018 sebesar 80,2\%. Hasil perhitungan analisis inferensial dengan metode regresi linier sederhana tersebut dikategorikan sangat tinggi karena integrasi indikator dalam kompetensi guru mampu memengaruhi hasil belajar ekonomi di SMA Negeri Rambipuji Tahun Ajaran 2017/2018 secara signifikan.

Berdasarkan penelitian yang telah dilakukan dapat diketahui bahwa kompetensi guru berpengaruh positif terhadap hasil belajar siswa. Hal ini sesuai dengan pendapat Mulyasa (2013: 57) bahwasannya pengujian kompetensi guru bermanfaat untuk beberapa hal yaitu sarana memetakan guru, alat seleksi penerimaan guru, sarana pengelompokan guru, acuan dalam pengembangan kurikulum, sarana untuk pembinaan guru, sarana pemberdayaan guru, dan alat untuk mendorong kegiatan dan hasil belajar. Salah satu manfaat kompetensi guru adalah sebagai alat untuk mendorong kegiatan dan hasil belajar.

Kegiatan pembelajaran dan hasil belajar siswa tidak saja ditentukan oleh manajemen sekolah, kurikulum, sarana dan prasarana pembelajaran, tetapi sebagian besar ditentukan oleh guru. Guru yang berhubungan langsung dengan siswa dalam kegiatan pembelajaran dan tugas utama guru adalah mendidik siswa. Guru harus memiliki kemampuan mewujudkan kinerja profesi guru dengan sebaik-baiknya, untuk mencapai tugas keprofesionalannya seperti yang tercantum dalam UU No. 14 tahun 2005. Bab IV Pasal 20 (a) tentang Guru dan Dosen disebutkan bahwa dalam melaksanakan tugas keprofesionalannya guru berkewajiban merencanakan, melaksanakan proses pembelajaran, serta menilai dan mengevaluasi hasil pembelajaran.

Berdasarkan olah data yang telah dilakukan, menunjukkan bahwa kompetensi guru mempunyai pengaruh yang signifikan terhadap hasil belajar siswa sesuai dengan pendapat Sudjana (2009:19) yang mengemukakan bahwa untuk keperluan analisis tugas guru sebagai pengajar, maka kemampuan guru atau kompetensi guru yang banyak hubungannya dengan usaha meningkatkan proses dan hasil belajar dapat diguguskan ke dalam empat kemampuan, yakni : merencanakan program belajar mengajar, melaksanakan atau mengelola proses belajar mengajar, menilai kemajuan proses belajar mengajar dan menguasai bahan pelajaran. Kemampuan guru atau kompetensi guru yang banyak hubungannya dengan usaha meningkatkan proses dan hasil belajar.

Penelitian tentang pengaruh kompetensi guru terhadap hasil belajar ekonomi di SMA Negeri Rambipuji tahun ajaran 2017/2018 ini menggunakan indikator kompetensi guru yang terdiri dari 2 kompetensi, diantaranya kompetensi pedagogik, dan kompetensi profesional. Kedua kompetensi ini dipilih karena berhubungan langsung dengan kegiatan pembelajaran di kelas. Melalui kompetensi pedagogik ini seorang guru memiliki kemampuan mengelola pembelajaran. Sejalan dengan pendapat Agus Wibowo dan Hamrin (2012: 110), kompetensi 
pedagogic adalah pemahaman guru terhadap anak didik, perencanaan, pelaksanaan pembelajaran, evaluasi hasil belajar, dan pengembangan anak didik untuk mengaktualisasikan sebagai potensi yang dimilikinya dan untuk mencapai hasil belajar siswa yang baik.

Kompetensi profesional merupakan kemampuan dasar tenaga pendidik. Guru akan disebut profesional, jika guru mampu menguasai keahlian dan keterampilan teoritik dan praktik dalam proses pembelajaran. Kompetensi ini cenderung mengacu kepada kemampuan teoritik dan praktik lapangan (mengajar di kelas). Sesuai dengan pendapat Muhlisin dalam Dewi (2014) tentang kompetensi profesional adalah "kemampuan guru dalam menguasai materi pelajaran secara luas dan mendalam yang memungkinkan mereka membimbing peserta didik dalam menguasai materi yang diajarkan sehingga siswa dapat memperoleh hasil belajar yang baik"

Kedua kompetensi tersebut dapat dilihat dari kemampuan guru dalam merencanakan program belajar mengajar, melaksanakan atau mengelola proses belajar mengajar di kelas, menilai dan mengadakan evaluasi proses belajar serta menguasai materi pelajaran yang diajarkan. Hal ini didukung dengan persentase kualifikasi guru ekonomi di SMA Negeri Rambipuji tahun ajaran 2017/2018 sudah terpenuhi. Artinya guru ekonomi yang mengajar di kelas XI IPS SMA Negeri Rambipuji sudah memenuhi kualifikasi yang sesuai dengan bidang yang diajarnya.

Kualifikasi guru merupakan keahlian yang diperlukan untuk melakukan pekerjaan sebagai seorang guru yang telah ditetapkan berdasarkan ketentuan yang berlaku. Guru pada tiap satuan pendidikan harus memenuhi kualifikasi akademik dengan bidang keilmuan yang relevan dengan bidang studi atau mata pelajaran yang mereka ajarkan di sekolahnya sehingga mereka disebut kompeten untuk bidang pekerjaannya. Hal ini didukung dengan sertifikat kompetensi yang dimiliki guru ekonomi kelas XI IPS SMA Negeri Rambipuji Tahun Ajaran $2017 / 2018$.

Berdasar hasil penelitian yang sudah dilakukan, kompetensi guru ekonomi kelas XI IPS di SMA Negeri Rambipuji tercermin dari kegiatan pembelajaran yang dilakukan. Kompetensi pedagogik yang dimiliki guru dapat dilihat melalui kegiatan pembelajaran dan kemampuan mengembangkan proses pembelajaran serta dapat memahami cara berfikir siswa. Pada saat kegiatan berlangsung di kelas guru hafal sebagian besar nama siswanya, jadi ketika melakukan penilaian individu di kelas guru dengan mudah mengetahui kemampuan siswa.

Guru ekonomi juga memiliki kompetensi profesional, kompetensi ini tercermin dalam kemampuan guru menguasai materi pembelajaran khususnya materi ekonomi secara mendalam dan mengembangkan materi sesuai dengan perkembangan teknologi. Guru menggunakan media pembelajaran edmodo sebagai salah satu penunjang kegiatan pembelajaran. Menurut Seamolec dalam Dharmawati (2017:43), edmodo adalah platform media sosial yang sering digambarkan sebagai facebook untuk sekolah dan dapat berfungsi lebih banyak lagi sesuai dengan kebutuhan. Pendapat tersebut didukung dengan hasil wawancara siswa kelas XI yang menjadi responden, sebagai berikut :

"Iya kak, saya paham materi yang disampaikan guru. Memang gurunya enak ketika menjelaskan dan ramah, saya sering bertanya tentang materi yang tidak saya pahami dan guru selalu menjawab sampai saya paham. Enaknya lagi suasana belajarnya ini santai kak tidak tegang. Ya walaupun kadang serius tapi saya tetap santai kak, soalnya enak ngajarnya dan saya paham materi ekonomi yang disampaikan."(Meri, 17th)

Apabila kedua kompetensi guru tersebut dikuasai guru akan mampu mendidik siswa dengan profesional, salah satu manfaat kompetensi guru adalah sebagai alat untuk mendorong kegiatan dan hasil belajar. Hasil belajar siswa sebagian besar ditentukan oleh guru karena guru merupakan salah satu faktor eksternal yang berhubungan langsung dengan siswa saat kegiatan pembelajaran. Hal ini didukung dengan pendapat Aunurrahman (2010:187), yang menyatakan bahwa keberhasilan belajar siswa disamping ditentukan oleh faktor internal juga ditentukan oleh faktor eksernal. Faktor eksternal adalah segala faktor yang ada dari luar diri siswa berpengaruh terhadap aktivitas dan hasil belajar yang dicapai siswa. Faktor eksternal yang mempengaruhi hasil belajar siswa adalah faktor guru, lingkungan sosial, kurikulum sekolah. Faktor tersebut erat hubungannya dengan aktivitas guru dalam kegiatan pembelajaran.

Aspek yang lain juga ditemukan dalam kegiatan penelitian, pada saat pembelajaran berlangsung guru sering bertanya kepada siswa. Menurut pendapat guru, hal ini digunakan untuk mengukur kemampuan dan 
sejauh mana tingkat pemahaman siswa yang akan berpengaruh terhadap hasil belajar. Hasil belajar siswa juga diperoleh dari kegiatan evaluasi pembelajaran yang dilakukan oleh guru. Kompetensi guru tercermin dari kemampuan guru melakukan penilaian pembelajaran dan mengevaluasi kegiatan pembelajaran yang telah dilakukan. Berdasarkan kegiatan penelitian, guru menggunakan beberapa penilaian seperti penilaian fortofolio, tes tulis dan presentasi. Pendapat tersebut didukung dengan hasil wawancara siswa kelas XI yang menjadi responden, sebagai berikut :

"Biasanya sih presentasi itu kak, kalo bagus dan bisa jawab pertanyaan dapat nilai plus juga. Presentasinya perkelompok, jadi semua dapat tugas masing-masing trus maju ke depan kelas semuanya. Kalau materi presentasinya ditentukan oleh gurunya kak. Selain presentasi membuat rangkuman juga kak, biasanya setelah guru menjelaskan kak kita diberi tugas merangkum kegiatan pembelajaran dan dapat nilai".(Adi,17th)

Berdasarkan hasil dari analisis data yang diperoleh dari angket dan wawancara yang dilakukan oleh peneliti dapat diketahui bahwa kompetensi guru dalam mengajar di kelas XI IPS SMA Negeri Rambipuji mempengaruhi hasil belajar, hal ini dapat dibuktikan dengan permasalahan yang ada dalam penelitian terjawab. Hipotesis yang menyatakan bahwa ada pengaruh yang signifikan antara kompetensi guru terhadap hasil belajar ekonomi di SMA Negeri Rambipuji tahun ajaran 2017/2018 diterima. Hal ini dibuktikan dari hasil analisis Uji $F$, bahwa besarnya $F_{\text {hitung }}=194,392$. Nilai $F_{\text {tabel }}=4,043$ dengan tingkat signifikansi $F=0,000$ maka $F_{\text {hitung }}$ yang berjumlah 194,392 lebih besar daripada $\mathrm{F}_{\text {tabel }}$ yaitu 4,043 dan tingkat signifikansi lebih kecil dari 0,05.

\section{PENUTUP}

Berdasarkan analisis data dan pembahasan mengenai pengaruh kompetensi guru terhadap hasil belajar, dapat disimpulkan bahwa kompetensi guru mempunyai pengaruh yang signifikan terhadap hasil belajar ekonomi di SMA Negeri Rambipuji Tahun Ajaran 2017/2018. Dan koefisien determinan ( $\mathrm{R}_{\text {square }}$ sebesar 80,2\%. Yang berarti bahwa kompetensi guru memberikan proporsi sumbangan sebesar $80,2 \%$ terhadap hasil belajar.

Berdasarkan kesimpulan di atas, maka saran dalam penelitian ini adalah sebagai berikut : guru disarankan untuk terus meningkatkan kompetensi guru, untuk meningkatkan kompetensi pedagogik dengan cara mengenali karakteristik peserta didik dan menguasai teori belajar, sehingga guru memiliki kemampuan mengelola pembelajaran yang lebih baik. Kompetensi profesional dengan cara menguasai kompetensi dasar mata pelajaran yang diampu dan mengembangkan materi pelajaran yang diampu secara kreatif, dan menggunakan model serta metode pembelajaran yang lebih bervariasi. Dengan memperhatikan cara-cara di atas diharapkan guru memiliki kompetensi mengajar yang lebih baik, sehingga dalam penyampaian materi di kelas dapat diterima siswa dan dapat meningkatkan hasil belajar siswa dengan maksimal. Bagi penelitian selanjutnya yang sejenis, sebaiknya menambahkan menambah indikator dalam penelitian ini dengan tidak hanya melihat kepada kompetensi pedagogik dan kompetensi profesional guru yang mempengaruhi hasil belajar siswa karena masih ada kompetensi sosial dan kompetensi kepribadian yang mempengaruhi hasil belajar siswa. Keempat kompetensi tersebut merupakan kompetensi yang harus dimiliki seorang guru.

\section{DAFTAR PUSTAKA}

Arikunto, S. 2014. Prosedur Penelitian: Satuan Pendekatan Praktik. Jakarta: Rineka Cipta.

Aunurrahman. 2010. Belajar dan Pembelajaran. Bandung: Alfabeta.

Dewi, Luh Retiantari. 2014. Pengaruh Kompetensi Pedagogik Dan Kompetensi Profesional Terhadap Hasil Belajar Siswa Dalam Mata Pelajaran Ekonomi Kelas X SMAN 4 Singaraja. Jurnal Pendidikan Ekonomi, Vol 4 No. 1.

Dharmawati. 2017. Penggunaan Media e-Learning Berbasis Edmodo Dalam Pembelajaran English for Business. Jurnal Sistem Informasi, Vol 01 No. 1. 
Mulyasa, E. 2013. Uji Kompetensi dan Penilaian Kinerja Guru. Bandung: PT Remaja Rosdakarya.

Undang-Undang RI No. 14 Tahun 2005. Tentang Guru dan Dosen. 2005. Jakarta: Departemen Pendidikan Nasional.

Undang-Undang RI No. 20 tahun 2003.Tentang Sistem Pendidikan Nasional. 2003. Jakarta: Departemen Pendidikan Nasional.

Sudjana, Nana. 2009. Dasar-Dasar Proses Belajar Mengajar. Bandung: Sinar Baru Algesindo.

Sugiyono. 2017. Statistik Untuk Penelitian. Bandung: Alfabeta.

Sugiyono. 2017. Metode Penelitian. Kuantitatif, Kualitatif, dan R\&D. Bandung: Alfabeta.

Wibowo, Agus dan Hamrin. 2012. Menjadi Guru Berkarakter. Yogyakarta: Pustaka Belajar. 